\title{
Telecoupled Groundwaters: New Ways to Investigate Increasingly De-Localized Resources
}

\author{
Robert Luetkemeier ${ }^{1,2, * \mathbb{C}}$, Fanny Frick-Trzebitzky ${ }^{1}$, Dženeta Hodžić ${ }^{1}$, Anne Jäger ${ }^{3}$, David Kuhn ${ }^{1}$ and \\ Linda Söller ${ }^{2}$ \\ 1 Institute for Social-Ecological Research (ISOE), 60486 Frankfurt am Main, Germany; frick@isoe.de (F.F.-T.); \\ hodzic@isoe.de (D.H.); kuhn@isoe.de (D.K.) \\ 2 Institute of Physical Geography, Goethe University Frankfurt, 60438 Frankfurt am Main, Germany; \\ Soeller@geo.uni-frankfurt.de \\ 3 Institute for Environmental Sciences, University Koblenz Landau, 76829 Landau, Germany; \\ jaegera@uni-landau.de \\ * Correspondence: luetkemeier@isoe.de; Tel.: +49-69-19-707-69-58
}

Citation: Luetkemeier, R.;

Frick-Trzebitzky, F.; Hodžić, D.; Jäger,

A.; Kuhn, D.; Söller, L. Telecoupled

Groundwaters: New Ways to

Investigate Increasingly De-Localized

Resources. Water 2021, 13, 2906.

https://doi.org/10.3390/w13202906

Academic Editors: Viviana Re and

Theresa Frommen

Received: 16 August 2021

Accepted: 14 October 2021

Published: 16 October 202

Publisher's Note: MDPI stays neutral with regard to jurisdictional claims in published maps and institutional affiliations.

Copyright: (c) 2021 by the authors. Licensee MDPI, Basel, Switzerland. This article is an open access article distributed under the terms and conditions of the Creative Commons Attribution (CC BY) license (https:// creativecommons.org/licenses/by/ $4.0 /)$.

\begin{abstract}
Groundwater is essential for drinking water provision and food production while hosting unique biodiversity and delivering key ecosystem services. However, overexploitation and contamination are prevailing threats in many regions worldwide. Even integrated governance schemes like the European Union Water Framework Directive often fail to ensure good quality and quantity conditions of groundwater bodies. Contributing factors are knowledge gaps on groundwater characteristics, limited financial, staff and land resources, as well as policy incoherencies. In this paper, we go further and argue that current groundwater challenges cannot be understood when considering the local situation within hydrologic boundaries only. New long-distance processes are at stake-so called telecouplings - that transgress watershed and administrative boundaries and significantly influence the state of local groundwater bodies. We provide three literature-based examples of European groundwater systems that are impacted by telecouplings, and we show how research and solution perspectives may change when acknowledging the de-localization of groundwater(s). We elaborate on virtual water trade, remote water supply, and seasonal tourist flows that connect sending, receiving and spillover systems. These processes can induce groundwater depletion and contamination but may also help to conserve the resource. Our hypothesis calls for a new spatial paradigm to groundwater management and highlights the need for transdisciplinary research approaches as envisioned in socio-hydrogeology.
\end{abstract}

Keywords: interdisciplinarity; sustainable groundwater management; water framework directive; social-ecological systems; socio-hydrogeology

\section{Studying Groundwater in New Spatial Relations \\ 1.1. Current Challenges in Groundwater Management}

Globally, groundwater is the most important source for drinking water [1], a key resource for food production [2] and is characterized by a unique biodiversity as well as essential ecosystem services [3]. Simultaneously, groundwater bodies are threatened by massive overexploitation [4] and pollution [5]. Regarding these threats, uncertainty persists in the interaction between quality and quantity under conditions of climate change [6], the impacts from diffuse pollution [5], pharmaceuticals and personal care products [7], the response of endemic invertebrate groundwater species to anthropogenic pressures [8], and future developments of societal groundwater demands [9]. This is also the case for Europe, where the European Union (EU) Water Framework Directive (WFD) provides an extensive regulatory context, which is considered a blueprint for other world regions [10]. The reasons that the WFD partly falls short of expectations are manifold and were already reviewed multiple times. Contributing factors are prevailing knowledge gaps on groundwater 
characteristics (hydrogeology, chemical, and ecological effects), limited resources (financial, staff, and land), scalar misfits (inter-sectoral integration and policy incoherencies), and legacies of historically very different water governance approaches within Europe [11].

\subsection{The Need for a New Spatial Paradigm}

While we consider the above findings as crucial from a local and historical explanatory domain, we specifically question a basic assumption in conventional groundwater management and research, which is the topological paradigm in which spatial proximity is essential to understand cause-effect relationships. Here, we hypothesize that a new spatial paradigm is required to understand and successfully manage today's groundwater challenges in the face of dynamic, translocal socio-hydro(geo)logical feedbacks [12,13] and hydro-social relations [14]. In this paper, we intend to underpin this hypothesis by drawing on recent conceptual developments in the telecoupling community [15] and exemplarily apply this framework to case studies in Europe (Spain, Germany, and Croatia). With this contribution, we aim to initiate a discussion about how space and scale must be rethought when dealing with groundwater as a slow-response, partly understudied, and invisible resource.

The shift from administrative to hydrological scales, introduced by the integrated water resources management (IWRM) approach decades ago [16], has been a key step to managing water resources sustainably. However, the river basin approach overlooks the hydrogeological spatial entities of aquifers that can span across different river basins [17]. Additionally, in the Anthropocene epoch, the basin-scale perspective is challenged by multiple social-ecological processes that easily transgress both hydrological and hydrogeological boundaries. Groundwater-a thoroughly localized resource-is increasingly subject to new supra-regional dynamics, such as climate change, virtual water trade, remote water supply, tourism, and policies [18]. Resulting groundwater impacts elude an explanation that attempts to consider the local situation only. Moreover, the experiences of rescaling water governance in the EU via the WFD have brought up new questions about adequate scales for managing water resources effectively, considering, for instance, the legitimacy of decision-making and representativeness of participation processes [19].

These developments show that today's groundwater problems cannot only be tackled by hydrogeologists alone, but they call for inter- and transdisciplinary research processes that consider interactions and relations beyond the domain of hydrogeology. Sociohydrogeology makes this point and requests a stronger recognition of social scientific insights into hydrogeological investigations $[13,20]$. This resonates well with transdisciplinary research overall, in which new applicable knowledge is co-produced by both an interdisciplinary team of scientists on the one hand and practitioners on the other hand [21,22]. An alternative mode of science is required for addressing these 'wicked problems' [23] in social-ecological systems (SES) around groundwater [24]. This also means that next to ecological and social processes, cultural dimensions need to be understood [25].

The objective of our contribution is to reconceptualize spatial relations of groundwater from an inter- and transdisciplinary perspective, taking the telecoupling framework as a boundary concept. This entails the challenge of bringing together multiple ways of and interests in framing a research question, defining the research objective, and selecting methods. Actors involved in this process need to acknowledge these differences while trying to find a common language [22]. A boundary concept enables researchers and stakeholders to develop a common terminology and understanding of a problem and its solution, which facilitates the process of integrating knowledge. At the same time, a boundary concept allows for contestations and fruitful disagreement among those involved [26].

Section 2 will introduce the telecoupling framework as a way to reconceptualize distal flows affecting groundwater and its potential to generate new understandings of how groundwater is entangled in social-ecological processes. Section 3 exemplarily applies the telecoupling framework to three case studies in Europe in order to carve out new insights that would have been unseen with conventional approaches to space, scale and time in 
groundwater research. Finally, Section 4 draws conclusions with respect to future research needs and revised ways to see, study, and manage groundwater.

\section{Telecoupling as a New Epistemological Entry Point to Study Groundwater \\ 2.1. Conceptualizing Distal Ground (Water) Flows}

Water flows not only from mountains to sea, from springs to pipes, and from pipes to taps, but also circulates across multiple scales in a variety of physical states (liquid, ice, and vapor), bio-chemical properties (minerals, dissolved oxygen, pollutants, and pathogens), ownerships (common property resource, tradeable good, and usufruct rights), and jurisdictions (transnational arrangements, national law, and communal law). This circulation is strongly influenced by power relations and political interests on where water ought to flow to or not, and it has been described as the hydrosocial cycle [14]. Infrastructure plays a key role in the reconfigurations of groundwater in the hydrosocial cycle, mainly in distributing (de-localizing) water mined at point sources in the form of pumps, pipes, and trucks and also in accessing and storing (de-temporalizing) water through reservoirs and tanks [27]. Policy and trade shape land and water use. As the locations of policy making, trade decisions, production, and consumption are often spread across the globe, and so are their effects on groundwater quantity and quality.

Concepts such as virtual water [28] and the water footprint [29] illustrate how water does not necessarily follow gravity but is rather (re)directed by human activities. Flows of virtual water are entailed in multiple products that are traded over long distances like vegetables, meat, textiles, and machinery [29]. Recently, scholars found that the international trade of agricultural products significantly contributes to groundwater depletion of non-renewable aquifers [30], critically exploiting important groundwater resources. Virtual water and water footprint approaches specifically focus on quantifying previously hidden water flows. However, they fall short in explaining the underlying socio-economic, cultural, and environmental causes and effects that give rise to the actual flow of virtual water [31]. Critical discussions of the concepts moreover highlight the limited comparability of water footprints across the globe against the background of local hydrological balances and the potential risk of underestimating the role of local water governance when highlighting global flows [32].

In this vein, the telecoupling framework raises new questions of scale in environmental governance [33,34]. The term 'telecoupling' was coined in 2013 to depict the close relationships within and between SES that are spatially, politically, and/or socio-economically separated from one another [15]. The framework received attention, especially in land systems sciences, as it provides a consistent framework to explain long-distance consequences of land use and land cover changes beyond the local domain [35]. The framework fundamentally focuses on flows of material, energy, or information from one location to another. Doing so, it distinguishes between certain SES, conceptualized in a specific case as sending systems being the origin of a flow and receiving systems being a flow's destination. Simultaneously, the framework hints towards the unintentional effects that may arise from the interaction of sending and receiving systems. It explores the consequences for so-called spillover systems. These are either impacted by or may impact the actual flow between the original systems [36]. While the three types of SES are connected via certain flows, they themselves are internally structured by agents, causes, and effects. While agents are conceptualized as human stakeholders who either try to support or inhibit the creation and maintenance of a flow, causes and effects are characterized by close feedback loops and are often difficult to distinguish. They depict the internal logic of why a certain SES works the way it does. Overall, constructing the individual SES along a certain flow offers the opportunity to grasp a more holistic picture of a certain phenomenon by recognizing relevant human-nature interactions that are beyond the local domain.

Against this background, telecouplings may provide the potential to shed light on distant relations that water management is increasingly confronted with [15]. The term 'distance' refers to both spatial Euclidean distance and socio-economic or political distance. 
This way, telecouplings add to the concepts of virtual water and water footprint in showing not only water trade to have consequences for local resources' availability-relevant social, cultural, economic, and historic processes come to the forefront with their intertwined spatio-temporal effects [37]. In conceptualizing distal feedbacks between SES and scaleeffects in local-global interactions, the telecoupling lens potentially allows for analyzing multiple flows that link groundwater bodies, infrastructures, policies, and people across places and scales. This potential has not yet been explored for the specific context of groundwater.

\subsection{Rethinking Scale and System Boundaries through Telecoupling}

We postulate that understanding the interaction of proximate and distal SES in which groundwater resources are entangled is key to sustainable groundwater governance. In this regard, the questions of taking the right scales and drawing the most suitable system boundaries are essential.

The problem of scale in environmental governance is an ongoing object of debate in sustainability and water governance literature $[19,38,39]$, as well as in critical geography and political ecology. Here, the need to explore the social, ecological, and political dimensions of and injustices involved in scale and scaling are emphasised [40,41]. In Europe, for instance, the intensification of agriculture has undermined groundwater protection in many areas despite the comparably strict policy framework through the WFD [42]. Here, 'global' market mechanisms in the agrifood sector interact with 'regional' and national policies on water and agriculture, as well as with 'local' specifics of hydrogeology, land, and water use [42]. This illustrates how scales in groundwater management are configured not only by hydrogeological entities, but also by policies and markets in other fields, including respective framings. The farmer bringing out manure on their fields may be considered an agent of a multinational agrifood system as much as a local stakeholder in a particular county. Local governance settings allow large-scale farming to form a backbone for respective flows in the international food trade, speaking to both the 'local' and the 'global' in a process of 'glocalization' [40]. At the same time, depicting inter- and multinational trade flows and climate change effects as a 'global' level of scale suggests a universality of interactions that conceals the variety of social-ecological processes people, species, and ecosystems find themselves in [43]. Hence, a hierarchical approach to scale in research and governance appears insufficient as (groundwater) "landscapes [are] no longer spatially enclosed" [44]. Indeed, aquifers, ecosystems, and people are connected through material and immaterial groundwater infrastructures and virtual water trade, transgressing hydrological and administrative boundaries.

Contemporary approaches to scale are analytically attuned to this processual nature of scale and scaling, and concomitant power imbalances. One prominent example featured in such research is 'glocalization,' which refers to global markets shaping local places, where some towns deliberatively develop to become part of global networks, whereas others are put off the map. Here, financial flows and the actors behind them have become powerful in determining how towns and regions develop, possibly even more powerful than democratically elected governmental bodies [40]. This has not only contributed to inequalities and effects of depoliticization in environmental governance. Moreover, experiences of rescaling in environmental governance have shown that adjusting administrative settings to environmental scales involves dilemmas of legitimacy and effectiveness, for instance, when a waterbody is managed by an entity that does not correspond to boundaries of governmental institutions [33]. Practices of (re)scaling include framings of scales by different actors and policies as well as trade (e.g., virtual water) and mobility (e.g., tourism). Lastly, scaling comes with shifts in power relations, associated struggles, and contestations over the power to control resource use [33,40].

Closely connected to the issue of scale is the setting of system boundaries. The fact that groundwater transgresses the confinements of hydrological systems raises the question on how to draw boundaries for researching and governing social-ecological processes 
around groundwater. Considering related flows in telecoupled groundwater systems, such as effects of policy, market, tourism, and virtual water, renders the task of distinguishing sending, receiving, and spillover systems more complex and empirically challenging. At what point in space and time do material water flows leave one system, flow between two systems, and enter a new one? What are analytical implications in terms of which agents, species, chemical elements, policies, land, and water uses belong to the same system? While this may clash with epistemological disciplinary boundaries (e.g., determining the boundaries of subterranean aquatic ecosystems), it is a useful heuristic for interdisciplinary research. Given the complexity of SES, the concept of telecouplings opens up analytical perspectives to alternative understandings of systems, relations, and flows [45].

\subsection{Governing Telecoupled Flows}

In its application to questions on water, the telecoupling framework might face similar critiques to concepts such as virtual water trade and the water footprint. First, water balances and definitions of 'overuse' and 'scarcity' might barely be comparable across regions. Second, it might be challenging to illustrate causal linkages between the flow of (virtual) water, motives for respective trade, and impacts on specific situations of scarcity empirically. To add, respective policy recommendations may be misleading [32]. In a similar vein, the early telecouplings literature has been critiqued for remaining on a descriptive level of causal linkages with limited substantiation from empirical data [41]. Moreoever, the overall idea of telecoupled systems bears the danger of reproducing a hierarchical notion of scale and overemphasising the agency of translocal networks.

However, recent studies have shown that telecoupling conceptually provides a coherent and flexible framework to account for questions of scale and system boundaries on a case-specific basis. The core of this strength is an understanding of systems that can incorporate relevant system components on a problem-centered basis. Hence, it may follow an epistemological system definition (e.g., analyzing interactions between elements irrespective of pre-defined system understandings) while still being open to considerations of how systems manifest locally (e.g., distinct 'real-world' places or administrative units) [46]. This way, the framework does not predefine system boundaries as static and perfectly confined to a certain location, but it enables the incorporation of relevant elements (e.g., agents), including their interactions (e.g., causes and effects) in a way that effectively frames a certain problem phenomenon. To operationalize this epistemological take of system views, a certain system understanding must be identified early in the research process based on a preliminary understanding of SES, pertaining elements, agents, and flows. Such a definition allows for the description of sending, receiving, and spillover systems to be in a singular location, as well as to span across places and scales [46]. Social-ecological processes across different points in time have been conceptualized as a dimension of telecoupling itself [46] or as an extension of the concept [47].

The telecoupling framework was first introduced with an explicit inter-and transdisciplinary interest in making environmental governance more effective. As a 'framework in the making' [45], it has been applied in various interdisciplinary contexts, with different approaches to integrate disciplinary perspectives. As Nielsen et al. argued, approaches have predominantly focused on integrating data on social and ecological flows in a unifying model, whereas a critical discussion of differing ontological understandings is only emerging [45]. Next to the aforementioned example of scale and space, the differing implicit understandings of governance in telecoupling research need to be examined critically [34]. The concept has the potential to spur interdisciplinary discussions over key assumptions on space, time, scale, and agency, while acknowledging the contributions and limits of disciplinary approaches and the merits of bringing them together [45]. Both the need for, and the difficulties involved in, bringing multiple ontological considerations together to address timely questions of global environmental change are an ongoing discussion in water research $[20,48]$. In addition, engaging in discussions on the processes and effects of scaling in environmental governance with those actively engaged in governance and 
policy making is a timely task in sustainability research [33]. It is against this background that we propose the telecoupling lens as a boundary concept to research groundwater in distal relations.

\section{Remote Relations Influencing European Groundwater Bodies}

In the following, our intention is to explore the potential of the telecoupling framework to serve as a boundary concept in framing inter- and transdisciplinary research on groundwater in distal relations. In lieu of a full empirical analysis, we provide case descriptions that highlight possible telecouplings. These descriptions are the result of an interdisciplinary process of defining shared objectives and selecting applicable approaches to create suitable boundary objects for researching groundwater in distal relations in Europe. For this purpose, the case study approach serves to substantiate the overall hypothesis and to draw generalizing conclusions. Cases were chosen by a set of criteria (e.g., quality/quantity constraints, flows affecting groundwater bodies, geographical coverage, different aquifer types) to ensure that cases are relevant from multiple disciplinary perspectives and for governing groundwater in practice. To ensure the latter, the case selection was repeatedly discussed with experts involved in the implementation and design of the EU Groundwater Directive.

Cases in Europe were chosen because of the seemingly contradictory situation of the WFD, which is often proclaimed as a sophisticated governance framework, and the continued groundwater degradation in the region. We particularly put a focus on cases in Europe against the background of the upcoming revision of the WFD for the post- 2027 period [10]. Still, qualitative and quantitative groundwater degradation has not been halted, with pollution from nitrate and pharmaceuticals being a prevailing threat for ecosystems and drinking water supply. Likewise, the recent drought years of 2018 and 2019 critically challenged European forests and impeded drinking water supply in some locations [49].

In the following subsections, we provide three examples in which a telecoupling perspective helps to uncover the systems that create certain flows contributing to local groundwater problems. Our literature-based examples illustrate multiple long-distance cause-effect relations that link sending and receiving systems beyond hydrological boundaries with particular effects on spill-over systems. We investigated (1) irrigation-driven virtual water flows from Spain, (2) remote water supply in Germany, and (3) tourism-induced depletion and pollution of Croatian groundwater bodies. Here, we follow the epistemological approach introduced above, which is following a loose working definition of a 'system of interest' that may consist in one or more aquifers to which certain land and water uses can be attributed to. These uses, in turn, may have an (adverse) effect that can, at least partly, be explained through social-ecological processes across large distances. We explore flows, causes, effects, and agents to illustrate instances of sending, receiving, and spillover, without a clear delineation of respective 'systems. The cases are briefly illustrated in Table 1. to provide a comparative overview, while the following subsections give more detailed case descriptions. Finally, this allows the raising of hypotheses and research questions for further analysis of telecoupled groundwater. 
Table 1. Comparative overview on exemplary telecoupling cases in Europe. Sections 3.1-3.3 give more detailed case descriptions.

\begin{tabular}{|c|c|c|c|c|}
\hline & & Spain & Germany & Croatia \\
\hline Flow & & Virtual Water & Physical Water & Tourists \\
\hline \multirow{3}{*}{ Sending System } & Agents & Farmers, retailers & $\begin{array}{l}\text { Dam operator, remote } \\
\text { water supplier, nature } \\
\text { conservation }\end{array}$ & $\begin{array}{l}\text { Travel agencies, tour } \\
\text { operators }\end{array}$ \\
\hline & Causes & $\begin{array}{l}\text { Historic water rights, trade } \\
\text { regulations, primacy of } \\
\text { irrigated agriculture over } \\
\text { water supply }\end{array}$ & $\begin{array}{l}\text { Historic water rights, } \\
\text { hydro-climatic conditions, } \\
\text { low competition for water } \\
\text { resources }\end{array}$ & $\begin{array}{c}\text { Marketing strategies, } \\
\text { hegemonic paradigm of } \\
\text { "holidays on the Adriatic } \\
\text { coast" }\end{array}$ \\
\hline & Effects & $\begin{array}{c}\text { GW depletion, salinization, } \\
\text { eutrophication, economic } \\
\text { gains }\end{array}$ & $\begin{array}{l}\text { Substantial ecosystem } \\
\text { alterations, tourism }\end{array}$ & $\begin{array}{c}\text { Satisfaction of consumer } \\
\text { preferences, drawback for } \\
\text { national tourism sector, } \\
\text { increased outbound air travel }\end{array}$ \\
\hline \multirow{3}{*}{ Receiving System } & Agents & $\begin{array}{l}\text { Consumers, retailers, } \\
\text { supermarkets, water } \\
\text { suppliers, farmers }\end{array}$ & $\begin{array}{l}\text { Local water supplier, } \\
\text { remote water supplier, } \\
\text { farmers, water consumers, } \\
\text { nature conservation }\end{array}$ & $\begin{array}{l}\text { Administration, tour } \\
\text { operators, tourism industry } \\
\text { actors, water suppliers, } \\
\text { nature conservation }\end{array}$ \\
\hline & Causes & $\begin{array}{l}\text { Paradigm of consuming } \\
\text { Mediterranean fruits, } \\
\text { primacy of water supply } \\
\text { over irrigated agriculture, } \\
\text { agricultural tradition }\end{array}$ & $\begin{array}{c}\text { Water quality (nitrate, } \\
\text { uranium hardness), } \\
\text { consumer perception of } \\
\text { water, farmer-water utility } \\
\text { conflicts, drought stressed } \\
\text { water supply }\end{array}$ & $\begin{array}{l}\text { Low-price destination, } \\
\text { favourable climate and } \\
\text { landscape, good water } \\
\text { infrastructure endowment } \\
\text { and accessibility, seasonal } \\
\text { population increase }\end{array}$ \\
\hline & Effects & $\begin{array}{l}\text { Nitrate pollution due to } \\
\text { intense livestock farming }\end{array}$ & $\begin{array}{l}\text { Satisfaction of consumer } \\
\text { preferences, quantitative } \\
\text { protection of local } \\
\text { GW-bodies }\end{array}$ & $\begin{array}{l}\text { Economic gains, seasonal } \\
\text { (ground)water depletion, } \\
\text { water quality deterioration, } \\
\text { remote water supply }\end{array}$ \\
\hline \multirow{3}{*}{ Spillover System } & Agents & $\begin{array}{l}\text { Farmers, migrant workers, } \\
\text { immigration agency }\end{array}$ & $\begin{array}{l}\text { Farmers, water utilities, } \\
\text { nature conservation }\end{array}$ & $\begin{array}{l}\text { Nature conservation, } \\
\text { administration, tourism } \\
\text { sector, water utilities }\end{array}$ \\
\hline & Causes & $\begin{array}{l}\text { Crises in home countries, } \\
\text { immigration regime }\end{array}$ & $\begin{array}{c}\text { Water protection } \\
\text { legislation, lack of coherent } \\
\text { policies }\end{array}$ & $\begin{array}{l}\text { Transboundary } \\
\text { geo-hydrological link, } \\
\text { untreated wastewater }\end{array}$ \\
\hline & Effects & $\begin{array}{l}\text { Remittances to families, } \\
\text { precarious working } \\
\text { conditions }\end{array}$ & $\begin{array}{l}\text { Qualitative risks for local } \\
\text { GW-bodies, land use } \\
\text { conflicts }\end{array}$ & $\begin{array}{l}\text { Contaminated groundwater, } \\
\text { cost-intensive water } \\
\text { treatment, (non-) EU policy } \\
\text { implementation challenges }\end{array}$ \\
\hline
\end{tabular}

\subsection{How Can Virtual Water Flows Lead to Groundwater Depletion in Spain?}

Export-oriented vegetable and fruit production in semi-arid south-eastern Spain has been critically overexploiting local groundwater bodies for decades, paired with increasing chemical pollution [50]. In 2020, Spain exported about six million tons of vegetables and seven million tons of fruits, mostly to other EU countries [51]. With an export quota of about $50 \%$ [52], the agricultural sector contributes up to $25 \%$ of the country's Gross Domestic Product (GDP). However, the strong EU trade business has only been possible due to intensive irrigation based on local groundwater resources. About $75 \%$ of groundwater abstracted in Spain is used by the agricultural sector [42]. Despite this well-known overexploitation, the strong dependency on groundwater as a key resource has prevented major shifts in production patterns. The quantitative pressure on groundwater bodies has also lead to quality problems, such as saltwater intrusion [53] and eutrophication [42].

So far, current management approaches have been confined to the regional scale and are considered to shift the problems while ignoring fundamental driving factors. 
'Technological-fixes', such as the desalinization of seawater [54], regional remote water networks, and more efficient irrigation methods have been favoured. However, these come with drawbacks, as desalinization is energy intensive, remote water networks stress water resources elsewhere, and more efficient irrigation methods carry the risk of rebound effects [55]. What these solution strategies have in common is their focus on the specific water needs on the regional scale. Factors contributing to overexploitation that lie beyond the region, or even in other countries, commonly have not been considered. One way of going beyond the explanatory domain of the local is the concept of virtual water. This concept illustrates the long-distance coupling between, e.g., fruit consumption in Central and Western Europe and groundwater-based irrigation in Spain by quantifying the total amount of water needed to produce and deliver a certain product [56]. However, solution strategies based on a virtual water perspective are often limited to aiming for efficiency gains on the production ('more crop per drop') and consumption site ('buy less waterintense products') [31]. Consequently, while the amount of water used per product might decrease, the total consumption may still increase and, thus, trigger continued groundwater exploitation.

In contrast, a telecoupling perspective can contribute to a more holistic, nuanced problem analysis and more sustainable, effective solutions by putting into focus Spain's groundwater-dependent food trade system. Here, the relevant flow is the virtual groundwater embedded in vegetables and fruits produced in Spain and consumed in other EU countries, such as Germany. This flow is generated by agrifood sector agents in both countries, for example, farmers in Spain who produce crops with irrigation water, transnational retail companies trading the products, supermarkets who are selling, and private households in Germany that are buying them. The retailers and supermarkets have especially gained much influence over shaping trade regulations, e.g., via private certification schemes for sustainable trade [57]. The causes in the sending system of Spain draw on a particular constellation of historical and contemporary water rights, trade regulations, and the primacy of the agricultural use of groundwater. These causes appear to be defended by irrigating farmers that have organized in water user boards, which have a strong position within the administrative bodies of the River Basin Districts. The apparent effects are locally declining groundwater tables with adjacent impacts on groundwater quality, ecosystems, and drinking water availability, as well as economic revenues for farmers. In this light, causes for the virtual water flow to arrive in the receiving system in Germany may be found in the paradigm of consuming fruits and vegetables all year round at low prices. In addition, the German agricultural sector does not produce a meaningful amount of fruits and vegetables for human consumption, as it focuses on meat and grain production [58]. At least in part, causes can also be identified in the water suppliers' drinking water protection agenda, which decreases the possibility of using groundwater for irrigation in agriculture. Hence, the effects are qualitative groundwater problems, e.g., nitrate pollution due to intense livestock farming. As spillover, we identified the precarious labor sector in Spain's agriculture. Vegetable production relies on low-paid migrant workers living and working under precarious conditions. Causes lie in the immigration regime of Spain bringing migrants into low-paid labor positions, exploiting political and economic crises in migrant's countries of origin. Effects are, e.g., remittances transferred by migrants to their families in Northern Africa, which directly affects local living conditions [59].

This exemplary application of the telecoupling framework to the case of groundwater over-exploitation in Spain suggests the inclusion of scales, systems, and stakeholders that are often neglected in the analyses of local groundwater problems. For instance, the relevance of the German agrifood system and EU trade regulations are rendered visible as structuring the virtual water flows. Acknowledging multiple scales and dimensions, other integral parts of Spain's agriculture sector can emerge analytically beyond the concept of virtual water, for example, the traditional water boards and their role in river basin management, EU food and trade policies, and Spain's migrant labor regime. As a result, governance strategies based on a telecoupling perspective would not be limited to finding 
solutions at the scale of river basins, but it would put into focus connections of retailers in propagating the availability of fruits and vegetables regardless of seasons and the established primacy of drinking water supply in Germany and Spain's labor market. This might involve the explicit addressing of these connections in EU policies, such as the Green New Deal, as well as establishing novel forms of collaboration among retailers, farmers, water providers, and migrant workers' associations.

\subsection{Can Remote Water Supply Mitigate Stress for Local Groundwater in Germany?}

In Sangerhausen, a city in the German federal state of Saxony-Anhalt, groundwater pollution and drought-induced water stress have increased the pressure on the regional drinking water supplier to satisfy consumers' demands. Anthropogenic activities (agriculture-induced nitrate concentrations) [60] and geogenic sources (uranium) [61], as well as recent water quantity constraints [62] have led to intense debates about reliability of the local drinking water supply in Sangerhausen. This is placed in the context of a federal state that is characterized by a semi-arid climate with comparably low precipitation rates in the south of about $500 \mathrm{~mm}$ [63]. Nevertheless, intensive large-scale agricultural production is possible due to productive loess soils [63]. However, the federal state recorded its driest summer on record in 2018 [64]. Additionally, decreasing precipitation, longer vegetation periods, and increasing evapotranspiration rates [65] have and will continue to shorten the period in which groundwater recharge is occurring, which may explain the declining groundwater tables since 1951 [66]. This trend is projected to continue in the future [63]. Public water demand is increasing due to rising temperatures [66], regardless of the population decline in the region since the 1990s [67]. For example, in 2018, domestic and industrial water use increased by $6 \%$ compared to the 10 -year average due to the extreme drought conditions [66].

As a result of the qualitative impairments of local groundwater resources around Sangerhausen and the quantitative constraints during the recent drought period [62], local drinking water provision has been connected to a remote water supply network that taps into a reservoir in the Harz Mountains [68]. This can be considered as a common strategy of communes in Saxony-Anhalt to bypass local groundwater problems (e.g., quality, quantity, operating costs) as today, remote water accounts for about $75 \%$ of the drinking water supplied in the state [69]. So far, technical and institutional measures to reduce nitrate pollution [69] and to remove the uranium concentration [70] have been unsuccessful.

Considering groundwater around Sangerhausen, not from the local but rather from a telecoupling perspective, substantially widens the lens to relevant processes. In this sense, we consider the water supplied via the remote water network as the flow coupling the receiving system of Sangerhausen to the sending system of the Harz Mountains. The latter is a less populated region and is thus characterized by a limited set of agents such as the governmental dam operator, the remote water supplier, and the nature conservation actors who are relevant in negotiating how local water resources should be utilized. Causes for the flow of water to originate in the Harz Mountains can be found in the supplier's historic water rights and the favorable hydro-climatic conditions of the region, while effects can be seen in substantial ecosystem alterations (due to reservoir creation and continuous water level fluctuations) and tourism potential. In Sangerhausen, as the receiving system, the set of agents is more diverse with both the remote and local water supplier, farmers, water consumers (e.g., households, trade, and commerce), and nature conservation actors. We identified the causes for the flow in the perception of the public as remote water is safer (e.g., health aspects) and more reliable (e.g., drought-induced water use is constrained) than local groundwater. The key effect that can be traced in the receiving system is the conservation of local groundwater in quantitative terms, as less water is used for drinking water supply. Despite this positive effect, groundwater quality may be negatively influenced because water protection zones legally disappear if granted water use rights remain unused for three years. Under the telecoupling framework, it makes sense to treat this negative effect as a spillover system in itself, in order to explore the associated set of agents, causes, and 
effects in more detail. Agents involved here are the farmers, the local water utilities, and the nature conservation actors who, as an effect, are likely to engage in a conflictual debate about new land use strategies when the legal requirements to protect certain groundwater recharge zones expires against actual WFD-requirements to limit nitrate concentration to a certain threshold. The respective causes can be found in the water protection legislation and as the misfit in policies touching upon agricultural practices and water management [42].

A telecoupling viewpoint in this particular groundwater challenge gives rise to insights that, so far, have not been covered in conventional groundwater management approaches. While water supply security may be enhanced on a local scale, the resilience of the entire remote water supply network on an inter-regional scale may be questioned against climate change phenomena, such as multi-annual and more severe droughts, as well as infrastructural threats (e.g., pipe damage due to heavy weather events or humaninduced manipulation). Thus, the telecoupling perspective allows the consideration of multiple scales. Not only has the drinking water supply system in Sangerhausen appeared as relevant but so has the groundwater ecosystems and the hydrological system around the reservoir. In addition, the telecoupling lens makes the structure of the stakeholder landscape more inclusive. In this sense, the consideration of agents in multiple systems (e.g., farmers in the receiving and the spillover system, water providers in sending and receiving systems, human and non-human water consumers in receiving and spillover systems) points to the need for integration of the respective voices in collaboratively developing perspectives for future groundwater management.

\subsection{How Does Tourism Induce Groundwater Deterioration in Croatia?}

Western south-eastern Europe is characterized by a Mediterranean, semi-arid climate and a complex hydrogeological structure of karstic aquifers [71]. Especially in Croatia, groundwater bodies have been increasingly under pressure from seasonal quantitative depletion and quality deterioration [72]. The tourism sector is easily identified as the major driver of these processes. Croatia has a total population of about 4 million people, yet annually hosts more than 17 million tourists from abroad, of which most come from Germany (17\%) [73]. Tourism has two major effects on groundwater bodies; the first is that the increase of water demand during tourist season peaks coincides with groundwater low-flow periods. This critically affects local resources by periodically drying out wells (e.g., in the coastal town Rijeka) [74] and decreasing the water quality, due to surface water intrusions (e.g., Ponikve reservoir on the island of Krk) [72]. Second, the construction boom in tourist accommodation has unfolded largely without appropriate sewage and wastewater systems, which has triggered the use of illegal septic tanks. As a result, point pollution of groundwater through untreated wastewater emerges with unknown effects on ecosystems and drinking water supply (e.g., in the Plitvice Lakes National Park) [75].

Currently, quantitative and qualitative groundwater issues in Croatia are approached locally, following a 'technological fix' paradigm. The seasonal scarcity of groundwater for drinking water supply during the peak tourism season is compensated by a regional remote water supply system from the coastal mainland town of Rijeka to the island of Krk [74]. Such supply side management activities are envisioned to meet the demand that is projected to further increase. To approach the qualitative deterioration from wastewater leakage, 'end-of-pipe' solutions are favored. The construction of wastewater treatment plants in the Plitvice Lakes National Park are planned, and the establishment of a crossborder karstic aquifer sanitary protection zone is targeted [76]. While the water transfer scheme is currently capable of meeting the increased water demands during the summer months, the construction of treatment plants lags behind planning [77].

The above-mentioned solution strategies follow conventional water management logics. In contrast, taking a telecoupling lens, starting with defining a flow of tourists, broadens the analytical potential and the subsequent solution strategies. Theoretically, Croatia can be considered the receiving system of tourists from sending systems of Central Europe and other Balkan countries. In the sending systems, agents such as tour operators 
and marketing agencies create an image of Croatia as an attractive tourist destination. The respective causes can be found in people's preferences to go on 'holiday on the Adriatic Coast' with the benefit of medium distance and a low-price environment. In their home countries, the effects are manifold such as drawbacks for the local tourism sector, outflow of money, and increased flight activities. With Croatia being the receiving system of the tourism flow, agents such as tour operators, accommodators, gastronomes, and event organizers interact with local water suppliers and wastewater treatment plant operators, as well as competing water users such as farmers. The causes for Croatia becoming a tourist attraction can be found in historical socio-political developments, as well as the favourable hydroclimatic conditions, the aesthetic landscape, the low-price offers compared to Western Europe, and the prospects of local entrepreneurs to gain income from tourism. Effects of the inflow of tourists are job and income creation on the one hand but particularly the qualitative and quantitative impairments of groundwater bodies as described above. Interestingly, the telecoupling lens allows us to not only consider a sending and receiving system but to go beyond and make visible a spillover system created by the tourism flow. As the karstic groundwater system forms a transboundary, highly permeable hydrogeological system, groundwater recharge in the area of the Plitvice Lakes in Croatia is connected to the region around the city of Bihać in Bosnia-Herzegovina [75]. The water supply system of Bihać may be challenged with a time lag due to groundwater pollution in tourist destinations in Croatia [75]. In this regard, agents such as the local water utilities in Bihac, the tourism operators, and the National Park in Croatia interact in a transnational domain. The causes for this can be found in the hydrological conditions and the diverging administrative and legislative situation, as Bosnia-Herzegovina does not fall legally under EU water regulations. The effect is an impaired water quality situation in Bihac with increasing costs for the city's water supply.

The Croatian case presented here displays a typical example in which supply-side management is followed to meet the increasing tourism-induced demand and mitigate pollution, following technological lines of thought. Against this situation, the telecoupling lens would not render the answers currently found as being wrong. Instead, it asks questions regarding scales, systems, and stakeholders that consider the origin, destination, and side effects of the tourism flow to find answers to protect groundwater bodies. For example, not only does the regional scale of the Adriatic coast appear as relevant, but so does the transnational boundary region between Croatia and Bosnia-Herzegovina. Similar to the case in Spain, a critical reflection of the sending system's common consumer paradigm of striving for 'holidays on the Adriatic Coast' is made possible. In Croatia, as the receiving system, questions apart from the supply-side management would pop up in this systems perspective by, e.g., addressing the strong position of the tourism sector in the country's GDP. With these multiple scales and system perspectives, stakeholders such as the BosnianHerzegovinian water suppliers or the German tour agencies appear as potential target agents when developing solutions for protecting the Croatian groundwater bodies.

\section{Conclusions}

Groundwater bodies are being overexploited and polluted globally with severe risks for both ecosystems and human activities such as drinking water supply or food production. While knowledge is available on why certain governance measures fail locally, the telecoupling lens suggests that a new spatial paradigm is required to manage groundwater bodies. In many places, groundwater becomes increasingly de-localized as multiple socialecological processes become relevant that easily transgress hydrological and administrative boundaries. In this paper, we argue that these processes have to be considered in research on groundwater that aims at contributing to sustainable groundwater management strategies. This requires a scale and space sensitive system's perspective that also considers indirect agents and processes as relevant and that acknowledges different ways of knowing groundwater(s). We presented conceptualizations of groundwater in telecoupled systems in three cases in Europe and discussed the benefits of applying the telecoupling lens to 
frame the 'local' groundwater problem. These case descriptions draw on a literature-based and inter- and transdisciplinary assessment of pressing groundwater issues in Europe. From our work, we draw the following conclusions:

- First, approaches commonly used to depict long-distance relations in the water sector, such as virtual water and water footprint analyses, go in the right direction, but, typically, they fall short in the explanation of the underlying causes of the studied phenomena. Here, the telecoupling framework can provide more insights to inform multi-level governance approaches by making visible the contradictory interactions between different hydrologic, political, or economic scales. Simultaneously, the characteristics of groundwater challenge the idea of a uniform framework of telecouplings in groundwater. An example is the extreme variability in time lags between actual pollution and its propagation and accumulation in an aquifer. In order to provide for an explanation of cause-effect relation, telecoupling effects need to be worked out at aquifer level.

- Second, the telecoupling framework explicitly accounts for unintended consequences of certain flows by highlighting the impacts in spillover systems. These side effects are often overlooked, but they are structurally built into the framework, providing new insights. The systems perspective allows an in-depth analysis of effects with its own cause and effect loops and relevant agents. As the case descriptions show, distinguishing receiving and spillover effects is not trivial in the case of groundwater due to limited knowledge on water flow behavior in karst aquifers. Here, conducting a rigorous study of sending, receiving, and spillover processes involves both the integration of multiple sets of data and the handling of uncertainties. In these contexts, ways in which agents handle uncertainties emerge as a crucial factor in cause and effect loops.

- Third, by taking the telecoupling lens to understand and explain a local groundwater challenge critically widens the picture of relevant stakeholders and particular forms of local knowledge. While considering the local scale only, supra-regional stakeholders are typically left out of sight or discussed as powerful but remote agents as an external force. Telecouplings specifically enable us to bring together stakeholders who are spatially separated but interacting closely. Bringing the interconnectivity of sending, receiving, and spillover systems to the fore makes the mutual dependency on these relations explicit. This creates new spaces for stakeholder interaction at eye level.

- Fourth, rethinking the scale, space, and time of groundwater flows through the telecoupling lens as a boundary concept opens up ways of linking approaches in inter- and transdisciplinary research without compromising the specific contributions of the disciplinary and professional perspectives involved. As we have shown in the discussion of three cases, the telecoupling framework allows for integrating knowledge about flows of policies, people, water, food, and chemical substances. By constantly refining the definition of a 'system of interest,' a shared understanding of cause, effect, and agents is created without delimiting definitions of system components and respective methods for their analysis.

- Finally, with its structured epistemological approach, the telecoupling framework provides researchers with a rich toolbox that allows the drawing of flows and boundaries, thereby making visible the scales, systems, and stakeholders relevant for making groundwater use more sustainable. Simultaneously, taking groundwater as an object of study in telecoupling research raises new questions in delineating sending, receiving, and spillover systems and analytically separating flows and systems. Here, we have only begun to tease out the overlaps that deserve further research attention. As our exploration indicates, applying the telecoupling lens to a fluid and hidden resource helps to further conceptualize telecouplings in light of debates of scale and scaling in environmental governance. 
Author Contributions: Conceptualization, R.L. and F.F.-T.; writing-original draft preparation, R.L.; writing—draft of exemplary cases, D.H., A.J., D.K. and L.S.; writing-review and editing, all authors; All authors have read and agreed to the published version of the manuscript.

Funding: This research and the APC was funded by the German Federal Ministry of Education and Research (BMBF) and conducted in the research project 'regulate-Regulation of Groundwater in Telecoupled Social-Ecological Systems', funding no. 01UU2003A. The Federal Ministry of Education and Research (BMBF) is funding the project within the framework of the Strategy. Research for Sustainability" (FONA) www.fona.de/en (accessed on 13 October 2021) as part of its Social-Ecological Research funding priority.

Acknowledgments: We would like to thank our project partners in the case study regions of Spain, Croatia, and Germany for the constructive discussions around local groundwater challenges. We would furthermore like to thank our student assistants Frederik Lam, Diana Molewijk, Katharina Koböck, Mirza Bečević, and Sophia Keller for their deliberate support. We thank all anonymous reviewers, particularly reviewer 4, for their thoughtful feedback and critical comments that helped improve the manuscript.

Conflicts of Interest: The authors declare no conflict of interest.

\section{References}

1. International Groundwater Resources Assessment Centre (IGRAC). Groundwater Overview: Making the invisible Visible. 2018. Available online: https:/ / www.un-igrac.org/sites/default/files/resources / files /Groundwater\%20overview\%20-\%20Making\% 20the\%20invisible\%20visible_Print.pdf (accessed on 22 February 2019).

2. Siebert, S.; Burke, J.; Faures, J.M.; Frenken, K.; Hoogeveen, J.; Döll, P.; Portmann, F.T. Groundwater use for irrigation-A global inventory. Hydrol. Earth Syst. Sci. 2010, 14, 1863-1880. [CrossRef]

3. Griebler, C.; Avramov, M. Groundwater ecosystem services: A review. Freshw. Sci. 2015, 34, 355-367. [CrossRef]

4. Döll, P.; Schmied, H.M.; Schuh, C.; Portmann, F.T.; Eicker, A. Global-scale assessment of groundwater depletion and related groundwater abstractions: Combining hydrological modeling with information from well observations and GRACE satellites. Water Resour. Res. 2014, 50, 5698-5720. [CrossRef]

5. Shukla, S.; Saxena, A. Global status of nitrate contamination in groundwater: Its occurrence, health impacts, and mitigation measures. In Handbook of Environmental Materials Management; Springer: Cham, Germany, 2018; pp. 1-21.

6. Green, T.R.; Taniguchi, M.; Kooi, H.; Gurdak, J.J.; Allen, D.; Hiscock, K.M.; Treidel, H.; Aureli, A. Beneath the surface of global change: Impacts of climate change on groundwater. J. Hydrol. 2011, 405, 532-560. [CrossRef]

7. Sui, Q.; Cao, X.; Lu, S.; Zhao, W.; Qiu, Z.; Yu, G. Occurrence, sources and fate of pharmaceuticals and personal care products in the groundwater: A review. Emerg. Contam. 2015, 1, 14-24. [CrossRef]

8. Griebler, C.; Malard, F.; Lefébure, T. Current developments in groundwater ecology—From biodiversity to ecosystem function and services. Curr. Opin. Biotechnol. 2014, 27, 159-167. [CrossRef] [PubMed]

9. Kraemer, D.K.; Ball, D.M.; Re, V.; Simmons, C.T.; Bothwell, T.; Verweij, H.J.; Mukherjee, A.; Moreau, M.F. The future of groundwater science and research. In Global Groundwater: Source, Scarcity, Sustainability, Security, and Solutions; Mukherjee, A., Scanlon, B.R., Aureli, A., Langan, S., Guo, H., Mckenzie, A.A., Eds.; Elsevier: Amsterdam, The Netherlands; Oxford, UK; Cambridge, MA, USA, 2021; pp. 503-518. ISBN 978-0-12-818172-0.

10. Moss, T.; Bouleau, G.; Albiac, J.; Slavíkova, L. WFD + 20: Assessing the European water framework directive. Water Altern. 2020, 13, 446-457.

11. Zingraff-Hamed, A.; Schröter, B.; Schaub, S.; Lepenies, R.; Stein, U.; Hüesker, F.; Meyer, C.; Schleyer, C.; Schmeier, S.; Pusch, M.T. Perception of bottlenecks in the implementation of the European water framework directive. Water Altern. 2020, 13, 1-26.

12. Sivapalan, M.; Savenije, H.H.G.; Blöschl, G. Socio-hydrology: A new science of people and water. Hydrol. Process. 2012, 26, 1270-1276. [CrossRef]

13. Re, V. Incorporating the social dimension into hydrogeochemical investigations for rural development: The Bir Al-Nas approach for socio-hydrogeology. Hydrogeol. J. 2015, 23, 1293-1304. [CrossRef]

14. Linton, J.; Budds, J. The hydrosocial cycle: Defining and mobilizing a relational-dialectical approach to water. Geoforum 2014, 57, 170-180. [CrossRef]

15. Liu, J.; Hull, V.; Batistella, M.; DeFries, R.; Dietz, T.; Fu, F.; Hertel, T.W.; Izaurralde, R.C.; Lambin, E.F.; Li, S.; et al. Framing sustainability in a telecoupled world. Ecol. Soc. 2013, 18, 26. [CrossRef]

16. Woodhouse, P.; Muller, M. Water governance-An historical perspective on current debates. World Dev. 2017, 92, 225-241. [CrossRef]

17. Foster, S.; Chilton, J.; Nijsten, G.-J.; Richts, A. Groundwater-A global focus on the 'local resource'. Curr. Opin. Environ. Sustain. 2013, 5, 685-695. [CrossRef]

18. Falkenmark, M.; Wang-Erlandsson, L.; Rockström, J. Understanding of water resilience in the Anthropocene. J. Hydrol. X 2019, 2, 100009. [CrossRef] 
19. Newig, J.; Schulz, D.; Jager, N.W. Disentangling puzzles of spatial scales and participation in environmental governance-The case of governance re-scaling through the European water framework directive. Environ. Manag. 2016, 58, 998-1014. [CrossRef]

20. Rangecroft, S.; Rohse, M.; Banks, E.W.; Day, R.; di Baldassarre, G.; Frommen, T.; Hayashi, Y.; Höllermann, B.; Lebek, K.; Mondino, E.; et al. Guiding principles for hydrologists conducting interdisciplinary research and fieldwork with participants. Hydrol. Sci. J. 2021, 66, 214-225. [CrossRef]

21. Jahn, T.; Bergmann, M.; Keil, F. Transdisciplinarity: Between mainstreaming and marginalization. Ecol. Econ. 2012, 79, 1-10. [CrossRef]

22. Krueger, T.; Maynard, C.; Carr, G.; Bruns, A.; Mueller, E.N.; Lane, S. A transdisciplinary account of water research. Wiley Interdiscip. Rev. Water 2016, 3, 369-389. [CrossRef]

23. Wiering, M.; Liefferink, D.; Boezeman, D.; Kaufmann, M.; Crabbé, A.; Kurstjens, N. The wicked problem the water framework directive cannot solve. The governance approach in dealing with pollution of nutrients in surface water in The Netherlands, Flanders, Lower Saxony, Denmark and Ireland. Water 2020, 12, 1240. [CrossRef]

24. Rica, M.; Petit, O.; Elena, L.-G. Understanding groundwater governance through a social ecological system framework-Relevance and limits. In Advances in Groundwater Governance; CRC Press: London, UK, 2017; pp. 55-72.

25. Ballestero, A. A Future History of Water; Duke University Press: Durham, UK, 2019.

26. Schleyer, C.; Lux, A.; Mehring, M.; Görg, C. Ecosystem services as a boundary concept: Arguments from social ecology. Sustainability 2017, 9, 1107. [CrossRef]

27. Alba, R.; Kooy, M.; Bruns, A. Conflicts, cooperation and experimentation: Analysing the politics of urban water through Accra's heterogeneous water supply infrastructure. Environ. Plan. E Nat. Space 2020, 0, 1-22. [CrossRef]

28. Hoekstra, A.Y. (Ed.) Virtual Water Trade. Proceedings of the International Expert Meeting on Virtual Water Trade; IHE Delft: Delft, The Netherlands, (Value of Water Research Report Series, 12); 2003.

29. Hoekstra, A.Y.; Mekonnen, M.M. The water footprint of humanity. Proc. Natl. Acad. Sci. USA 2012, 109, 3232-3237. [CrossRef] [PubMed]

30. Dalin, C.; Wada, Y.; Kastner, T.; Puma, M.J. Groundwater depletion embedded in international food trade. Nature 2017, 543, 700-704. [CrossRef]

31. Beltrán, M.J.; Velázquez, E. The political ecology of virtual water in southern Spain. Int. J. Urban Reg. Res. 2015, 39, 1020-1036. [CrossRef]

32. Wichelns, D. Virtual water and water footprints. Compelling notions, but notably flawed. GAIA-Ecol. Perspect. Sci. Soc. 2011, 20, 171-175. [CrossRef]

33. Newig, J.; Moss, T. Scale in environmental governance: Moving from concepts and cases to consolidation. J. Environ. Policy Plan. 2017, 19, 473-479. [CrossRef]

34. Newig, J.; Lenschow, A.; Challies, E.; Cotta, B.; Schilling-Vacaflor, A. What is governance in global telecoupling? Ecol. Soc. 2019, 24, 26. [CrossRef]

35. Friis, C.; Nielsen, J. Global land-use change through a telecoupling lens: An introduction. In Telecoupling: Exploring Land-Use Change in a Globalised World; Springer: Cham, Switzerland, 2019; pp. 1-15.

36. Liu, J.; Dou, Y.; Batistella, M.; Challies, E.; Connor, T.; Friis, C.; Millington, J.D.; Parish, E.; Romulo, C.L.; Silva, R.F.; et al. Spillover systems in a telecoupled Anthropocene: Typology, methods, and governance for global sustainability. Curr. Opin. Environ. Sustain. 2018, 33, 58-69. [CrossRef]

37. Deines, J.M.; Liu, X.; Liu, J. Telecoupling in urban water systems: An examination of Beijing's imported water supply. Water Int. 2016, 41, 251-270. [CrossRef]

38. Moss, T.; Newig, J. Multilevel water governance and problems of scale: Setting the stage for a broader debate. Environ. Manag. 2010, 46, 1-6. [CrossRef]

39. Syed, T.; Choudhury, E.; Islam, S. An assessment of scale-sensitivity in policy design and implementation of the EU water framework directive within the context of the Danube Basin. Water Altern. 2020, 13, 634-658.

40. Swyngedouw, E. Globalisation or 'glocalisation'? Networks, territories and rescaling. Hist. Econ. Soc. Bull. 2004, 17, 25-48. [CrossRef]

41. Goodman, M.K.; Boykoff, M.T.; Evered, K.T. Contentious geographies: Environmental knowledge, meaning, scale. In Contentious Geographies: Environmental Knowledge, Meaning, Scale; Goodman, M.K., Boykoff, M.T., Evered, K.T., Eds.; Ashgate: Hampshire, Englang; Burlington, VT, USA, 2008; pp. 1-23.

42. Foster, S.; Custodio, E. Groundwater resources and intensive agriculture in Europe-Can regulatory agencies cope with the threat to sustainability? Water Resour. Manag. 2019, 33, 2139-2151. [CrossRef]

43. Adger, W. Scales of governance and environmental justice for adaptation and mitigation of climate change. J. Int. Dev. 2001, 13, 921-931. [CrossRef]

44. Terkenli, T.S. New landscape spatialities: The changing scales of function and symbolism. Landsc. Urban Plan. 2005, 70, 165-176. [CrossRef]

45. Nielsen, J.Ø.; Friis, C.; Niewöhner, J. Beyond integration: Exploring the interdisciplinary potential of telecoupling research. In Telecoupling: Exploring Land-Use Change in a Globalised World; Friis, C., Nielsen, J.Ø., Eds.; Springer: Cham, Switzerland, 2019; pp. 339-355, ISBN 3030111059. 
46. Friis, C.; Nielsen, J.Ø. On the system. Boundary choices, implications, and solutions in telecoupling land use change research. Sustainability 2017, 9, 974. [CrossRef]

47. Matias, D.M. The Extended Present: Conceptualizing Tempocoupling and Sustainability Archaeology; Institute for Social-Ecological research: Frankfurt/Main, Germany, 2020.

48. Rusca, M.; di Baldassarre, G. Interdisciplinary critical geographies of water: Capturing the mutual shaping of society and hydrological flows. Water 2019, 11, 1973. [CrossRef]

49. EurEau. The Impact of Drought on Drinking Water. 2020. Available online: https://www.eureau.org/documents/drinkingwater/briefing-note/5111-briefing-note-on-the-impact-of-drought-on-drinking-water/file (accessed on 26 April 2021).

50. Rodríguez-Estrella, T. The problems of overexploitation of aquifers in semi-arid areas: The Murcia Region and the Segura Basin (South-east Spain) case. Hydrol. Earth Syst. Sci. Discuss. 2012, 9, 5729-5756. [CrossRef]

51. FEPEX. La Exportación Española de Frutas y Hortalizas Frescas Supera Los 14.500 Millones de Euros en 2020. Available online: https:/ / www.fepex.es/noticias/detalle/exportacion-espanola-frutas-hortalizas-2020 (accessed on 12 August 2021).

52. MAPA. Frutas y Hortalizas. Available online: https://www.mapa.gob.es/es/agricultura/temas/producciones-agricolas/frutasy-hortalizas/informacion_general.aspx (accessed on 12 August 2021).

53. Argamasilla, M.; Barberá, J.A.; Andreo, B. Factors controlling groundwater salinization and hydrogeochemical processes in coastal aquifers from southern Spain. Sci. Total Environ. 2017, 580, 50-68. [CrossRef] [PubMed]

54. Swyngedouw, E.; Williams, J. From Spain's hydro-deadlock to the desalination fix. Water Int. 2016, 41, 54-73. [CrossRef]

55. Lankford, B.; Closas, A.; Dalton, J.; Gunn, E.L.; Hess, T.; Knox, J.W.; van der Kooij, S.; Lautze, J.; Molden, D.; Orr, S.; et al. A scale-based framework to understand the promises, pitfalls and paradoxes of irrigation efficiency to meet major water challenges. Glob. Environ. Chang. 2020, 65, 102182. [CrossRef]

56. Dumont, A. Flows, Footprints and Valus: Visions and Decisions on Groundwater in Spain. Doctoral Thesis, Complutense University of Madrid, Madrid, Spain, 2015.

57. Vos, J.; Hinojosa, L. Virtual water trade and the contestation of hydrosocial territories. Water Int. 2016, 41, 37-53. [CrossRef]

58. BMEL. Agrarpolitischer Bericht der Bundesregierung 2019. 2019. Available online: https://www.bmel.de/SharedDocs/ Downloads/DE/Broschueren / Agrarbericht2019.pdf;jsessionid=D199BB1B3EE323E5447FD3C3FDEEBC61.live922?_blob= publicationFile\&v $=4$ (accessed on 12 August 2021).

59. United Nations Conference on Trade and Development (UNCTAD). Impact of Remittances on Poverty in Developing Countries; United Nations: Geneva, Switzerland, 2011.

60. Hahn, H.-J.; Fuchs, A.; Berkhoff, S. Biomonitoring Nitrat 2020 in Sachsen-Anhalt: Endbericht. 2020. Available online: https://lhw.sachsen-anhalt.de/fileadmin/Bibliothek/Politik_und_Verwaltung/Landesbetriebe/LHW/neu_PDF/5.0_GLD/ Dokumente_GLD/Berichte_Dokumente_GW/2020_Endbericht_Biomonitoring_Nitrat.pdf (accessed on 15 October 2021).

61. Landesamt für Umweltschutz Sachsen-Anhalt (LAU). Urankonzentrationen im Grundwasser von Sachsen-Anhalt; Landesamt für Umweltschutz Sachsen-Anhalt (LAU): Halle, Germany, 2007.

62. Landkreis Mansfeld-Südharz. Allgemeinverfügung zur Beschränkung des Gemeingebrauchs i.S.v. §29 Abs. 1 WG LSA (Wassergesetz für das Land Sachsen-Anhalt) im Landkreis Mansfeld-Südharz. 2018. Available online: https://www.mansfeldsuedharz.de/ de/ausgabe/wasserknappheit-landkreis-verbietet-entnehmen-von-wasser-aus-oberflaechengewaessern.html (accessed on 12 August 2021).

63. Hattermann, F.F.; Weiland, M.; Huang, S.; Krysanova, V.; Kundzewicz, Z.W. Model-supported impact assessment for the water sector in central Germany under climate change-A case study. Water Resour. Manag. 2011, 25, 3113-3134. [CrossRef]

64. Imbery, F.; Friedrich, K.; Koppe, C.; Janssen, W.; Pfeifroth, U.; Daßler, J.; Bissolli, P. Wärmster Sommer im Norden und Osten Deutschlands. 2018. Available online: https://www.dwd.de/DE/leistungen/besondereereignisse/temperatur/20180906 _waermstersommer_nordenosten2018.pdf?_blob=publicationFile\&v=7 (accessed on 25 June 2020).

65. Riedel, T.; Weber, T.K.D. Review: The influence of global change on Europe's water cycle and groundwater recharge. Hydrogeol. J. 2020, 28, 1939-1959. [CrossRef]

66. Möhler, F.; Wiesner, C.; Ruhland, A. Auswirkungen des klimawandels und anpassungsstrategien für das wasserwerk colbitz in Sachsen-Anhalt. Grundwasser 2021, 26, 47-60. [CrossRef]

67. Landesamt für Umweltschutz Sachsen-Anhalt. Bericht zur Öffentlichen Wasserversorgung in Sachsen-Anhalt für das Jahr 2018. 2018. Available online: https://lau.sachsen-anhalt.de/fileadmin/Bibliothek/Politik_und_Verwaltung/MLU/LAU/Wasser/ Wassertechnik_downloads/Dateien_Ber_2018/200604_OEWVLSA2018_Bericht_bf.pdf (accessed on 26 March 2021).

68. Landesamt für Umweltschutz Sachsen-Anhalt. Die Öffentliche Wasserversorgung in Sachsen-Anhalt 2018 (Karte): Betreiber Der Öffentlichen Wasserversorgung und Ihre Versorgungsräume. 2020. Available online: https://lau.sachsen-anhalt.de/fileadmin/ Bibliothek/Politik_und_Verwaltung/MLU/LAU/Wasser/Wassertechnik_downloads/Dateien_Ber_2018/oewv_18_karte1 .pdf (accessed on 26 March 2021).

69. Pommer, G.; Koch, H. Zu viel Nitrat im Trinkwasser: Säuglinge dürfen jetzt nur noch mineralwasser trinken: Sangerhausen-Was die Behörden in dem Fall den betroffenen Bürgern empfehlen. Mitteldeutsche Zeitung, 1 June 2018. Available online: https: / www. mz.de/lokal/sangerhausen/zu-viel-nitrat-im-trinkwasser-sauglinge-durfen-jetzt-nur-noch-mineralwasser-trinken-1442903 (accessed on 12 August 2021). 
70. Kranert-Rydzy, H. Trinkwasser in Mansfeld-Südharz: Uran abfall lagert neben brunnen. Mitteldeutsche Zeitung, 23 October 2013. Available online: https:/ /www.mz.de/mitteldeutschland/trinkwasser-in-mansfeld-sudharz-uran-abfall-lagert-neben-brunnen2086531 (accessed on 12 August 2021).

71. Bonacci, O.; Željković, I.; Galić, A. Karst rivers' particularity: An example from Dinaric karst (Croatia/Bosnia and Herzegovina). Environ. Earth Sci. 2013, 70, 963-974. [CrossRef]

72. Oštrić, M.; Horvat, B.; Lončarić-Trinajstić, I.; Benac, Č.; Ružić, I.; Rubinić, J. Research of water resources on Karst Islands on the example of the Island of Krk (Croatia). Water Obs. Inf. Syst. Balk. Ctries 2010, 1-12. Available online: http:/ /balwois.com/wpcontent/uploads / old_proc/ffp-1835.pdf (accessed on 3 December 2020).

73. Croatian Bureau of Statistics. Tourism 2019. Statistical Reports. 2020. Available online: https://www.dzs.hr/Hrv_Eng/ publication/2020/SI-1661.pdf (accessed on 11 August 2021).

74. Slavuj, L.; Čanjevac, I.; Opačić, V.T. Water supply as a factor of sustainable tourism development on the Island of Krk. Hrvat. Geogr. Glas. Geogr. Bull. 2009, 71, 23-41. [CrossRef]

75. Babinka, S. Multi-Tracer Study of Karst Waters and Lake Sediments in Croatia and Bosnia-Herzegovina: Plitvice Lakes National Park and Bihac Area. Doctoral Dissertation, University of Bonn, Bonn, Germany, 2007.

76. Philipp, D. Development of a Study on the Establishment of the Klokot (Bihac) Spring Cross-Border Sanitary Protection Zones. 2020. Available online: https:/ / www.google.com/url?sa=t\&rct=j\&q=\&esrc=s\&source=web\&cd=\&ved=2ahUKEwjWiI-eq8 zzAhWphP0HHRoRAyYQFnoECAIQAQ\&url=https\%3A\%2F\%2Fdocuments1.worldbank.org\%2Fcurated \%2Fen \%2F8767816 02132853101\%2Fpdf\%2FFinal-Report.pdf\&usg=AOvVaw3FPsblZivcELVw_3ji0Cig (accessed on 13 August 2021).

77. Vurnek, M.; Brozinčević, A.; Kepčija, R.M.; Frketić, T. Analyses of long-term trends in water quality data of the Plitvice Lakes National Park. Fundam. Appl. Limnol. 2021, 194, 155-169. [CrossRef] 